\title{
Peran Pendamping dalam Pemberdayaan Masyarakat Miskin melalui Program Keluarga Harapan
}

\author{
Evi Rahmawati ${ }^{凶}$, Bagus Kisworo \\ Pendidikan Luar Sekolah, Fakultas Ilmu Pendidikan, Universitas Negeri Semarang
}

DOI: $10.15294 /$ pls.v1i2.16271

\section{Info Artikel}

\section{Sejarah Artikel:}

Diterima Agustus 2017

Disetujui November 2017

Dipublikasikan Desember 2017

\section{Keywords:}

complementary roles; family hope program; community development

\begin{abstract}
Abstrak
Penelitian ini bertujuan mendeskripsikan peran pendamping, faktor penghambat dan pendukung dalam pendampingan Program Keluarga Harapan di Kecamatan Semarang Tengah. Penelitian ini menggunakan pendekatan kualitatif, pendamping sebagai subjek penelitiannya. Wawancara, observasi dan dokumentasi sebagai Teknik pengumpulan data. Keabsahan data menggunakan triangulasi sumber, metode dan teori. Analisis datanya menggunakan siklus interaktif. Hasil penelitian menunjukkan bahwa pendamping memiliki empat peran keterampilan yaitu peran fasilitatif, pendidik, representatif/perwakilan masyarakat, dan teknis. Faktor internal yang menjadi kendala adalah sulitnya peserta untuk mengumpulkan berkas data, dan beradaptasi dengan lingkungan baru pendamping memerlukan waktu lama. Faktor eksternal yang menjadi kendala adalah penginformasian dari pusat sifatnya mendadak, jarak tempuh pendamping ke tempat pendampingan cukup jauh dan lokasi tempat pendampingan yang berada di gang sempit. Faktor pendukung adalah antusiasme penerima bantuan serta sarana yang memadai.
\end{abstract}

\begin{abstract}
This study aims to describe the role of counselors, inhibiting factors and supporters in the assistance of Family Hope Program in Central Semarang District. This research uses a qualitative approach, companion as a research subject. Interview, observation, and documentation as data collection techniques. The validity of data using triangulation of sources, methods, and theories. The data analysis uses an interactive cycle. The results showed that the companion had four roles of skills namely facilitative roles, educators, representatives/representatives of society, and technical. Internal factors that become obstacles are the difficulty of participants to collect data files, and adapt to new environment companion takes a long time. External factors that become obstacles is the information from the center of the sudden, the distance to the counselee far enough away and the location of the mentoring located in a narrow alley. Supporting factors are the enthusiasm of beneficiaries and adequate facilities.
\end{abstract}

\footnotetext{
$凶$ Alamat korespondensi:
}

E-mail: eviraldian@gmail.com 


\section{PENDAHULUAN}

Indonesia merupakan salah satu negara dengan tingkat kepadatan penduduk yang tinggi. Kemiskinan sudah menjadi masalah global yang dialami oleh seluruh negara di dunia. Masalah kemiskinan menjadi kendala yang rumit sehingga suatu negara tidak dapat memiliki kemampuan untuk menghapus kemiskinan secara sendiri. Mayoritas masyarakat Indonesia berada pada taraf ekonomi yang rendah, hal ini menyebabkan angka kemiskinan di Indonesia semakin bertambah tinggi dari tahun ke tahun. Dengan kondisi seperti ini membuat Indonesia menghadapi persoalan-persoalan rumit seperti tingkat kriminalitas tinggi, tingkat pendidikan rendah, dan tingkat kesehatan yang rendah. Pemerintah sebagai pemegang kekuasaan tertinggi berhak untuk mengatur dan mengurus negaranya sendiri. Sebagaimana yang tercantum dalam Undang-Undang Dasar Republik Indonesia Tahun 1945 yang mengamanatkan bahwa negara berkewajiban untuk melindungi segenap bangsa Indonesia dan memajukan kesejahteraan sosial dalam rangka mewujudkan keadilan sosial bagi seluruh rakyat Indonesia.

Penanganan kemiskinan yang ada diperlukan suatu program yang dapat memberdayakan masyarakat miskin. Dalam rangka percepatan penanggulangan kemiskinan sekaligus pengembangan kebijakan di bidang perlindungan sosial, sejak tahun 2007 Pemerintah Indonesia telah melaksanakan Program Keluarga Harapan (PKH). Di Kota Semarang memulai PKH pada tahun 2013. Program serupa telah dilaksanakan dan cukup berhasil di beberapa negara yang dikenal dengan Conditional Cash Transfer (CCT) atau bantuan tunai bersyarat. Menurut Rahayu (2012:128) "Program Keluarga Harapan (PKH), yaitu program pemberian uang tunai kepada RTSM berdasarkan persyaratan dan ketentuan yang telah ditetapkan dengan melaksanakan kewajibannya". PKH difokuskan untuk meningkatkan kualitas sumber daya masyarakat miskin melalui pemberdayaan kaum ibu, dan mendorong agar anaknya tetap bersekolah sesuai dengan data yang ditetapkan oleh Badan Pusat Statistik (BPS) sebagai target peserta. Menurut
Kementerian Sosial (2016), PKH merupakan program perlindungan sosial yang memberikan bantuan tunai kepada Rumah Tangga Sangat Miskin (RTSM) dengan persyaratan tertentu. Tujuan dari program ini adalah mengurangi angka dan memutus rantai kemiskinan, meningkatkan kualitas sumber daya manusia, serta merubah perilaku yang kurang mendukung peningkatan kesejahteraan dari kelompok paling miskin. Peserta PKH diwajibkan memenuhi persyaratan dan komitmen yang terkait dengan upaya peningkatan kualitas sumberdaya manusia yaitu pendidikan dan kesehatan. Sasaran peserta PKH adalah Keluarga Miskin (KM) dan yang memiliki komponen kesehatan (ibu hamil, nifas, balita, anak prasekolah) dan komponen pendidikan (SD sederajat, SMP sederajat, SMA sederajat) atau anak 7 - 21 tahun yang belum menyelesaikan pendidikan wajib 12 tahun, penyandang disabilitas berat, dan lanjut usia di atas 70 tahun.

Menteri Sosial menjelaskan bahwa pada tahun 2017 dana yang dialokasikan oleh pemerintah adalah sebesar $\mathrm{Rp} 11,4$ triliun. Bantuan PKH akan disamakan sebesar Rp 1.900.00 per tahun dengan penyaluran empat kali dalam setahun. Penyaluran pertama sebesar Rp 500.000, kedua Rp 450.000, ketiga Rp 500.000 dan keempat Rp 450.000. Beberapa ketentuan bantuan PKH adalah (1) Bantuan tetap sebagaimana SK Menteri Sosial No. 23/HUK/2016 berlaku dalam satu tahun, (2) Bantuan komponen peserta $\mathrm{PKH}$ diberikan kepada maksimal 3 anggota keluarga sesuai kriteria kepesertaan, (3) Bantuan komponen peserta $\mathrm{PKH}$ diberikan dengan jumlah nominal terbesar dari komponen kepesertaan, (4) Bantuan komponen kesehatan kehamilan keempat dan berikutnya tidak dihitung sebagai komponen penerima bantuan. Indeks besaran dana yang di terima peserta PKH sebagaimana pada tabel 1.

Menurut Rahayu (2012) dalam jangka pendek maupun jangka panjang, manfaat $\mathrm{PKH}$ adalah (1) dalam jangka pendek yaitu memberikan income effect melalui pengurangan beban pengeluaran rumah tangga miskin; (2) dalam jangka panjang dapat memutus rantai kemiskinan RTM melalui peningkatan kualitas 
kesehatan/nutrisi, pendidikan dan kapasitas pendapatan anak (price effect) dan memberikan kepastian akan masa depannya (insurance effect); (3) merubah perilaku keluarga miskin yang relatif kurang mendukung peningkatan kesejahteraan antara lain disebabkan oleh kurangnya informasi mengenai hak, manfaat, keuntungan, dan kesempatan, serta tingginya biaya tidak langsung (transport, seragam, dan lain-lain) dan opportunity cost (anak bekerja lebih "menguntungkan" dari pada sekolah); (4) mengurangi pekerja anak, yaitu mencegah turunnya anak-anak bekerja di jalanan, serta mencegah RTM menjadi tuna sosial dan/ penyandang masalah kesejahteraan social; (5) peningkatan kualitas pelayanan publik melalui complementary perbaikan layanan pendidikan dan kesehatan (supply side), pengembangan sistem perlidungan sosial masyarakat miskin (demand side), sekaligus penguatan desetralisasi, dan (6) percepatan pencapaian MDGs melalui indikator kemiskinan, pendidikan, ibu hamil, pengurangan kematian balita, dan peningkatan kesetaraan gender.

Tabel 1. Indeks Besaran Dana yang Diterima Peserta PKH

\begin{tabular}{clc}
\hline No. & \multicolumn{1}{c}{ Komponen Bantuan } & Indeks Bantuan \\
\hline 1. & Bantuan tetap & 500.000 \\
2. & Bantuan ibu hamil dan menyusui & 1.200 .000 \\
3. & Bantuan anak usia di bawah enam (6) tahun & 1.200 .000 \\
4. & Bantuan peserta Pendidikan setara SD/MI atau sederajat & 450.000 \\
5. & Bantuan peserta Pendidikan setara SMP/MTs atau sederajat & 750.000 \\
6. & Bantuan peserta Pendidikan setara SMA/MA atau sederajat & 1.000 .000 \\
7. & Bantuan penyandang disabilitas berat & 3.100 .000 \\
8. & Bantuan lanjut usia 70 tahun ke atas & 1.900 .000 \\
\hline \multicolumn{2}{l}{ Sumber: Kementerian Sosial (2016) }
\end{tabular}

Menurut Kementerian Sosial (2016) terdapat beberapa kewajiban peserta PKH yaitu diantaranya ibu hamil/nifas adalah pemeriksaan kehamilan di fasilitas kesehatan sebanyak 4 kali dalam 3 kali trisemester, melahirkan oleh tenaga kesehatan di fasilitas kesehatan, pemeriksaan kesehatan 2 kali sebelum bayi usia 1 bulan. Bayi dan Balita yaitu usia 0-11 bulan imunisasi lengkap serta pemeriksaan berat badan setiap bulan, usia 6-11 bulan mendapat suplemen vitamin A, usia 1-5 tahun imunisasi tambahan dan pemeriksaan berat badan setiap bulan, usia 5 6 tahun pemeriksaan berat badan setiap 1 bulan dan mendapatkan vitamin A sebanyak 2 kali dalam setahun, usia 6-7 tahun timbang badan di fasilitas kesehatan.

Anak sekolah usia 6-21 tahun yang belum menyelesaikan pendidikan dasar (SD, SMP, SMA), terdaftar di sekolah/pendidikan kesetaraan, minimal $85 \%$ kehadiran dikelas. Penyandang disabilitas berat yaitu pemeliharaan kesehatan sesuai kebutuhan, pemeriksaan kesehatan dapat dilakukan oleh tenaga kesehatan melalui kunjungan ke rumah (home care). Lansia miskin di atas 70 tahun yaitu pemeriksaan kesehatan dapat dilakukan oleh tenaga kesehatan atau mengunjungi puskesmas santun lanjut usia (jika tersedia), dan mengikuti kegiatan sosial (day care dan home care).

Menurut Kementerian Sosial (2016), apabila peserta tidak memenuhi komitmennya maka berlaku beberapa ketentuan; pengurangan bantuan adalah $10 \%$ setiap bulannya sebelum penyaluran periode berikutnya, peserta tidak mendapat bantuan jika seluruh komponen anggota tidak memenuhi kewajiban selama 3 bulan berturut-turut, peserta $\mathrm{PKH}$ yang seluruh komponen anggotanya dalam 6 bulan berturutturut tidak memenuhi komitmen maka disamping bantuan tidak diberikan, ia akan dikeluarkan. Bagi pendamping yang peserta $\mathrm{PKH}$ dampingannya tidak memenuhi kondisionalitas akan diberikan sanksi berupa mendapat teguran secara lisan maupun tertulis (SP-1 sampai SP3), dan penundaan pembayaran honorarium. Pendampingan komponen kesehatan dan pendidikan menurut Kementerian Sosial (2016) dilakukan dengan ketentuan bahwa pendamping PKH berkewajiban mengadakan pertemuan kelompok bulanan dengan peserta $\mathrm{PKH}$ dampingannya, pendamping PKH berkewajiban 
memastikan bantuan komponen kesehatan dan pendidikan sampai pada sasaran.

Adapun persyaratan umum sebagai pedamping $\mathrm{PKH}$ adalah tidak berkedudukan sebagai CPNS/PNS/TNI/POLRI; siap dan bersedia bekerja purna waktu serta ditempatkan pada wilayah sesuai dengan kebutuhan $\mathrm{PKH}$; tidak berkedudukan sebagai pengurus, anggota dan atau berafiliasi partai politik; tidak pernah dan atau tersangkut kasus hukum baik pidana maupun perdata; usia minimal 19 (sembilan belas) tahun maksimal 45 (empat puluh lima) tahun pada bulan April 2016; bebas dari narkoba dan zat adiktif lainnya; sehat jasmani dan rohani; lulusan perguruan tinggi atau sekolah yang program studinya terakreditasi bagi pendidikan sarjana, diploma, dan SMK; tidak terikat kontrak kerja dengan pihak lain; mampu mengoperasikan komputer dan menggunakan office automation; bersedia menandatangani pakta integritas apabila terpilih menjadi pendamping dan operator $\mathrm{PKH}$ tahun 2016; serta mengikuti seluruh tahapan seleksi. Sedangkan persyaratan khusus untuk posisi pendamping $\mathrm{PKH}$ meliputi: 1) pendidikan diploma IV/sarjana pekerjaan sosial atau kesejahteraan sosial; (a) mengikuti pelatihan di bidang pekerjaan sosial dan penyelenggaraan kesejahteraan social, (b) memiliki pengalaman praktik pekerjaan sosial/pelayanan kesejahteraan sosial. 2) Pendidikan sarjana dan diploma di bidang ilmu-ilmu sosial terapan diutamakan; (a) mengikuti pelatihan di bidang pekerjaan sosial dan penyelenggaraan kesejahteraan social, (b) memiliki pengalaman praktik pekerjaan sosial/pelayanan kesejahteraan sosial.

3) Pendidikan sarjana atau diploma di bidang sosial diutamakan; (a) mengikuti pelatihan di bidang pekerjaan sosial/kesejahteraan social, (b) memiliki pengalaman praktik pekerjaan sosial/pelayanan kesejahteraan sosial. 4) Sekolah Menengah Kejuruan (SMK) kesejahteraan sosial/pekerjaan sosial/ keperawatan, diutamakan; (a) mengikuti pelatihan di bidang pekerjaan sosial dan penyelenggaraan kesejahteraan social, (b) memiliki pengalaman praktik pekerjaan sosial/pelayanan kesejahteraan sosial.
Dalam pelaksanaan $\mathrm{PKH}$, terdapat pendamping yang merupakan aktor penting dalam mensukseskan program PKH. Pendamping $\mathrm{PKH}$ adalah sumber daya manusia yang direkrut dan dikontrakkerjakan yang ditetapkan oleh Kementerian Sosial sebagai pelaksana pendampingan di tingkat kecamatan. Keberhasilan PKH dipengaruhi oleh implementasi pemberdayaan masyarakat miskin (RTSM) dan peran pendamping. Menurut Departemen Sosial (2009), pendampingan sosial merupakan suatu proses relasi sosial antara pendamping dengan klien yang bertujuan memecahkan masalah, memperkuat dukungan, mendayagunakan berbagai sumber dan potensi dalam pemenuhan kebutuhan hidup, serta meningkatkan akses klien terhadap pelayanan sosial dasar, lapangan kerja, dan fasilitas pelayanan publik lainnya.

Berdasarkan pengertian yang dimaksud peran pendamping adalah suatu tugas atau aktivitas yang dilakukan oleh seseorang yang menjadi penghubung masyarakat dengan berbagai lembaga terkait dan diperlukan bagi pengembangan. Pendamping sering dikaitkan dengan pekerja sosial dan kegiatan pendampingan merupakan pekerjaan sosial. Ada beberapa Undang-Undang yang secara langsung mengakui dan mengatur adanya keberadaan pekerja sosial. Diantaranya Undang-Undang Nomor 11 tahun 2009 tentang Kesejahteraan Sosial. Pada pasal 1 angka 4 yang dimaksud pekerja sosial adalah seseorang yang bekerja, baik di lembaga pemerintah maupun swasta yang memiliki kompetensi dan profesi pekerjaan sosial, dan kepedulian dalam pekerjaan sosial yang diperoleh melalui pendidikan, pelatihan, dan atau pengalaman praktik pekerjaan sosial untuk melaksanakan tugas-tugas pelayanan dan penanganan masalah sosial. Pada UndangUndang nomor 23 Tahun 2002 tentang Perlindungan Anak pada pasal 1 ayat (14) yang dimaksud pendamping adalah pekerja sosial yang mempunyai kompetensi professional dalam bidangnya. Menurut Keputusan Menteri Sosial No.10/HUK/2007, pekerja sosial adalah seseorang yang memiliki kompetensi professional dalam pekerjaan sosial yang diperolehnya 
melalui pendidikan formal atau pengalaman praktik di bidang pekerjaan sosial atau kesejahteraan sosial yang diakui secara resmi oleh pemerintah dan melaksanakan tugas professional pekerjaan sosial.

Pekerja sosial dapat dipahami sebagai seseorang yang mempunyai kompetensi dan keahlian yang diperoleh melalui pendidikan atau pelatihan dalam menyelenggarakan berbagai pelayanan sosial. Pendamping merupakan pihak kunci yang menjembatani penerima manfaat dengan pihak-pihak lain yang terlibat di tingkat kecamatan maupun dengan program di tingkat kabupaten/kota. Tugas dan tanggungjawab pendamping $\mathrm{PKH}$ secara umum adalah melaksanakan tugas pendampingan kepada RTSM/KSM peserta PKH. Selain tugas tersebut, pendamping juga berperan dalam pemberdayaan masyarakat miskin yang menjadi sasaran program.

Menurut Habibullah (2011), pendamping PKH memiliki kedudukan sebagai mitra pemerintah dan mitra masyarakat sehinga dituntut untuk menjembatani berbagai kepentingan yang datang dari pemerintah maupun kepentingan masyarakat. Peran pendamping PKH berdasarkan konsep peran community worker adalah sebagai peran dan keterampilan fasilitatif. Peran yang berkaitan denga motivasi, kesempatan, dan dukungan bagi masyarakat. Beberapa tugas yang berkaitan dengan peran ini adalah menjadi model, melakukan negosiasi dan mediasi, memberikan dukungan, membangun konsensus bersama, serta melakukan pengorganisasian dan pemanfaatan sumber. Di sisi lain, ada juga sebagai peran dalam keterampilan mendidik. Pendamping berperan aktif sebagai agen yang memberi masukan positif dan direktif berdasarkan pengetahuan dan pengalaman masyarakat yang didampinginya. Membangkitkan kesadaran masyarakat, menyampaikan informasi, melakukan konfrontasi, menyelenggarakakn pelatihan bagi masyarakat adalah beberapa tugas yang berkaitan dengan peran pendidik. Peran lain yaitu dalam keterampilan representasi/perwakilan masyarakat. Peran ini dilakukan dalam kaitannya dengan interaksi antara pendamping dengan lembaga-lembaga eksternal atas nama dan demi nama kepentingan masyarakat dampingannya. Pekerja sosial dapat bertugas mencari sumber-sumber, melakukan pembelaan, menggunakan media, meningkatkan hubungan masyarakat, dan membangun jaringan kerja. Sebagai peran akhir yaitu dalam keterampilan teknis. Mengacu pada aplikasi keterampilan yang bersifat praktis, pendamping dituntut tidak hanya mampu menjadi "manajer perubahan" yang mengorganisasikan kelompok, melainkan pula mampu melakukan tugas-tugas teknis sesuai dengan berbagai keterampilan dasar seperti melakukan riset, penggunaan komputer, presentasi verbal dan tertulis, serta kemampuan untuk mengontrol dan mengelola keuangan.

Berdasarkan pada berbagai ulasan mengenai peran seorang pendamping dalam program $\mathrm{PKH}$, sebaiknya memang harus ada control oleh masyarakat apakah peran pendamping tersebut sudah dijalankan sebagaimana mestinya. Dengan demikian penelitian ini dilakukan demi tujuan hal tersebut, serta dapat dijelaskan adanya faktor penghambat dan pendukung sebagaimana yang ada di lapangan dari adanya peran pendamping dalam rangka penyelenggaraan program $\mathrm{PKH}$.

\section{METODE}

Penelitian ini menggunakan pendekatan kualitatif. Sesuai dengan pendapat Moleong (2010:6) digunakan untuk "fenomena tentang apa yang dialami oleh subjek penelitian secara holistik dan dengan cara deskripsi dalam bentuk kata-kata dan bahasa pada suatu konteks khusus alamiah dan dengan memanfaatkan berbagai metode alamiah". Penggunaan metode kualitatif ini didasarkan atas beberapa pertimbangan. Pertama, menyesuaikan metode kualitatif lebih mudah apabila berhadapan dengan kenyataan jamak. Kedua, metode ini menyajikan secara langsung hakikat hubungan antara peneliti dan responden. Ketiga, metode ini lebih peka dan lebih dapat menyesuaikan diri dengan banyak penajaman pengaruh bersama terhadap pola-pola nilai yang dihadapi 
Teknik pengumpulan data yang digunakan adalah melalui observasi, wawancara dan dokumentasi. Peneliti menggunakan metode observasi karena dalam penelitian kualitatif ini, peneliti harus mengetahui secara langsung keadaan atau kenyataan lapangan sehingga dapat diperoleh informasi yang jelas. Selain observasi peneliti menggunakan wawancara. Teknik wawancara dalam penelitian ini adalah untuk mengungkap data selengkap mungkin dari informan mengenai peran pendamping di Kecamatan Semarang Tengah yang ditujukan dapat membantu dalam proses pemberdayaan masyarakat miskin penerima PKH. Data yang diperoleh dari hasil wawancara mencakup pendampingan $\mathrm{PKH}$ terhadap masyarakat penerima $\mathrm{PKH}$, serta mengidentifikasi dan mendeskripsikan faktor pendukung dan penghambat pendamping PKH. Oleh Karena itu, dalam penelitian ini peneliti menggunakan teknik wawancara terstruktur. Dimana peneliti telah mempersiapkan instrumen atau pedoman serta daftar pertanyaan yang ditujukan kepada subjek dan informan. Alasan peneliti menggunakan teknik wawancara terstruktur karena menurut peneliti, teknik ini dapat mempermudah peneliti dalam menggali informasi sebanyak-banyaknya. Serta peneliti menggunakan dokumentasi. peneliti juga memperoleh data tambahan dari sumber tertulis berupa arsip dan dokumen terkait penyelenggaraan $\mathrm{PKH}$ dan pendampingan serta buku-buku yang berkaitan dengan fokus penelitian. Teknik dokumentasi dalam penelitian ini bertujuan untuk mencari data yang berkaitan dengan pelaksanaan peran pendamping dalam pemberdayaan masyarakat miskin melalui Program Keluarga Harapan di Kecamatan Semarang Tengah antara lain daftar penerima $\mathrm{PKH}$, daftar pendamping, profil PKH, struktur organisasi PKH. Dokumen digunakan dalam penelitian sebagai sumber data karena dalam banyak hal dokumen sebagai sumber data dimanfaatkan untuk menguji, menafsirkan, bahkan untuk meramalkan.

Teknik analisis data yang digunakan dalam penelitian ini adalah pengumpulan datadata yang diperoleh di lapangan baik berupa catatan di lapangan, gambar, dokumen dan lainnya diperiksa kembali, diatur, dan kemudian diurutkan. Reduksi data digunakan memilih hal-hal pokok yang sesuai dengan fokus penelitian. Reduksi data merupakan suatu bentuk analisis yang menajamkan, mengarahkan, membuang yang tidak perlu dan mengorganisasi. Data-data yang telah direduksi memberikan gambaran yang lebih tajam tentang hasil pengamatan dan mempermudah peneliti untuk mencarinya sewaktu-waktu. Penyajian data adalah sekumpulan informasi yang telah tersusun yang memberi kemungkinan adanya penarikan kesimpulan dan pengambilan tindakan. Penarikan kesimpulan merupakan langkah akhir dalam analisis data. Reduksi data, penyajian data, dan penarikan kesimpulan serta verifikasi data sebagai sesuatu yang saling berinteraksi sebelum, selama dan sesudah pengumpulan data dalam bentuk yang sejajar, terpadu dan sinergis. Tiga alur kegiatan analisis dalam kegiatan pengumpulan data tersebut merupakan proses siklus yang interaktif yang digunakan dalam penelitian ini.

\section{HASIL DAN PEMBAHASAN Peran Pendamping}

Pendamping PKH memiliki kedudukan sebagai mitra pemerintah dan mitra masyarakat sehinga dituntut untuk menjembatani berbagai kepentingan yang datang dari pemerintah maupun kepentingan masyarakat. Peran pendamping $\mathrm{PKH}$ berdasarkan konsep peran community worker yang dikemukakan Habibullah (2011) adalah peran dan keterampilan memfasilitasi yang merupakan peran yang berkaitan dengan pemberian motivasi, kesempatan, dan dukungan bagi masyarakat. Beberapa tugas yang berkaitan dengan peran ini antara lain menjadi model, melakukan mediasi dan negosiasi, memberi dukungan, membangun konsensus bersama, serta melakukan pengorganisasian dan pemanfaatan sumber. Sesuai dengan yang disampaikan Departemen Sosial (2009) bahwa pendampingan adalah suatu proses pemberian kemudahan (fasilitas) yang diberikan pendamping kepada klien dalam mengidentifikasi kebutuhan dan memecahkan masalah serta mendorong tumbuhnya inisiatif 
dalam proses pengambilan keputusan, sehingga kemandirian klien secara berkelanjutan dapat diwujudkan.

Pendamping $\mathrm{PKH}$ sebagai animator, dengan memberikan rangsangan, dorongan, memberikan motivasi kepada keluarga penerima manfaat PKH dengan memenuhi kewajiban PKH biasanya hanya dilakukan apabila penerima manfaat $\mathrm{PKH}$ tidak memenuhi kewajiban PKH. Selain itu, pendamping juga melakukan mediasi dan negosiasi yang dilakukan kepada pihak layanan kesehatan maupun pendidikan yang tidak menjalankan fungsinya. Peran pendamping sebagai konsensus, fasilitasi kelompok, dan pengorganisasian berjalan sangat baik. Pengorganisasian yang dilakukan tidak hanya sebatas pembentukan kelompok penerima manfaat $\mathrm{PKH}$ untuk saluran informasi dan komunikasi saja, kelompok tersebut juga dipersiapkan dan diberdayakan untuk kegiatan seperti Kelompok Usaha Bersama (KUBE) serta usaha kelompok seperti Warung Elektronik (EWarung) agar penerima manfaat tidak bergantung lagi dengan $\mathrm{PKH}$ ketika program berakhir.

Peran dan keterampilan dalam mendidik, pendamping berperan aktif sebagai agen yang memberi masukan positif dan direktif berdasarkan pengetahuan dan pengalamannya serta bertukar gagasan dengan pengetahuan dan pengalaman masyarakat yang didampinginya, membangkitkan kesadaran masyarakat, menyampaikan informasi, menyelenggarakan pelatihan bagi masyarakat adalah beberapa tugas yang berkaitan dengan peran pendidik. Hal tersebut sesuai dengan tujuan pekerjaan sosial yang diungkapkan oleh Damanik (2008) bahwa tujuan pekerjaan sosial diantaranya adalah meningkatkan kemampuan manusia untuk memecahkan masalah-masalah, menghadapi kesulitan-kesulitan, dan melaksanakan tugastugas kehidupannya secara efektif. Untuk mencapai tujuan tersebut, pekerja sosial mengakses hambatan-hambatan yang membatasi kemampuan klien untuk melaksanakan tugastugas kehidupannya.

Pekerja sosial juga mengidentifikasikan sumber-sumber dan kekuatan-kekuatan, meningkatkan keterampilan-keterampilan untuk menghadapi masalah-masalah dalam kehidupan, mengembangkan rencana-rencana pemecahan masalah, dan mendukung usaha-usaha klien untuk menciptakan perubahan-perubahan di dalam kehidupan dan situasi-situasi mereka. seperti pada Pertemuan Peningkatan Kemampuan Keluarga (P2K2) pendamping PKH Kecamatan Semarang Barat melakukan P2K2 yang bertujuan untuk meningkatkan pengetahuan dan kesadaran peserta $\mathrm{PKH}$ tentang pentingnya pendidikan dan kesehatan dalam memperbaiki kualitas hidup keluarga di masa depan. Disinilah pendamping berperan sebagai pendidik yang menyampaikan muatan edukasi mengenai pendidikan dan pengasuhan anak, ekonomi, kesehatan dan perlindungan anak, lansia dan disabititas.

Pada peran dan keterampilan representasi/perwakilan masyarakat, peran ini dilakukan dalam kaitannya dengan interaksi antar pendamping dengan lembaga-lembaga eksternal atas nama dan demi kepentingan masyarakat dampingannya. Pekerja sosial dapat bertugas mencari sumber-sumber, melakukan pembelaan, menggunakan media, meningkatkan hubungan masyarakat, dan membangun jaringan kerja, mengunjungi penyedia layanan. Kegiatan ini merupakan salah satu kegiatan yang sangat vital dalam keberlangsungan maupun peningkatan mutu program. Pendamping memantau kelancaran dan kelayakan kegiatan pelayanan, mengantisipasi permasalahan yang ada dalam program sehingga bisa melakukan tindakan yang sifatnya mencegah kegagalan kelancaran program daripada memperbaikinya.

Sesuai dengan tujuan pekerjaan sosial menurut Pincus \& Minahan dalam Hermawati (2001:13) diantaraya adalah "mengaitkan orang dengan sistem yang dapat menyediakan sumber pelayanan dan kesempatan yang dibutuhkan, dan meningkatkan kemampuan pelaksanaan sistem tersebut secara efektif dan berperikemanusiaan". Pendamping menjalankan peran sebagai perwakilan masyarakat dengan mengunjungi layanan kesehatan seperti puskesmas dan posyandu, serta layanan pendidikan tempat anak-anak peserta $\mathrm{PKH}$ bersekolah. Hal tersebut 
merupakan tugas pedamping sebagai perwakilan masyarakat yang dilakukan demi kelancaran peserta PKH.

Peran dan keterampilan teknis didapatkan bahwa pendamping membantu peserta $\mathrm{PKH}$ dalam mengelola keuangan pada KUBE. Pendamping mengelola keuangan KUBE dengan membuat Laporan Pertanggung Jawaban (LPJ). Karena dana yang dikeluarkan untuk KUBE tidak sedikit, pendamping membantu peserta PKH untuk membuat LPJ. Peserta diminta mengumpulkan kwintansi setelah melakukan pembelian. Lalu selanjutnya pendamping yang menyusunnya menjadi LPJ. Selain itu pendamping juga mengoperasikan media elektronik dengan baik misalnya pada saat P2K2, pendamping mempresentasikan materinya dengan kemampuan komunikasi yang baik dengan peserta PKH. Dalam hal ini terbukti bahwa pendamping berperan dalam keterampilan teknis. Berdasarkan hasil penelitian tersebut, sejalan dengan pengertian peran dan keterampilan teknis merupakan peran yang cenderung menonjol dilakukan oleh pendamping PKH. Meskipun peran tersebut tidak secara langsung mempengaruhi penerima manfaat PKH. Peran tersebut menjadi indikator keberhasilan pendampingan yang dilihat secara administratrif. Peran tersebut berkaitan dengan keterampilan untuk melakukan riset, menggunakan komputer, dan melakukan presentasi verbal dan tertulis, serta kemampuan untuk mengontrol dan mengelola keuangan.

\section{Faktor Penghambat dan Pendukung}

Pelaksanaan pendampingan di Kecamatan Semarang Tengah menemui beberapa kendala. Faktor penghambat atau kendala dalam penelitian ini dibedakan dalam faktor internal dan eksternal. Faktor internal yang menjadi kendala dalam pendampingan adalah sulitnya peserta untuk mengumpulkan berkas data atau formulir pemutakhiran. Selain itu untuk beradaptasi dengan lingkungan baru pendamping memerlukan waktu. Untuk pertama ada perasaan grogi namun akhirnya seiring berjalannya waktu grogi dapat teratasi, serta sulitnya kehadiran peserta PKH untuk tepat waktu bahkan banyak yang tidak hadir dengan alasan yang beragam. Padahal pendamping dan peserta sudah membuat kesepakatan namun tetap saja masih banyak yang melanggar tidak sesuai dengan komitmennya.

Faktor eksternal yang menjadi kendala adalah penginformasian dari pusat yang sifatnya mendadak yang menyebabkan hasil yang dicapai kurang maksimal. Lalu jarak yang ditempuh pendamping ke tempat pendampingan cukup jauh dan terkadang terjebak macet yang menyebabkan tertundanya pendampingan. Serta lokasi tempat pendampingan yang berada di gang-gang sempit dan kurangnya tanda atau nama gang yang menyulitkan pendamping untuk mencari tempat pendampingan yang lokasinya berpindah pindah.

Adapun yang menjadi faktor pendukung adalah mengenai peran pendamping dalam pemberdayaan masyarakat miskin melalui program keluarga harapan keberhasilanya tidak terlepas dari adanya faktor pendukung yang menyertainya. Faktor pendukung dalam proses pendampingan mencakup tingkat antusias keikutsertaan penerima bantuan PKH. Penerima PKH selalu aktif dalam mengikuti setiap pembimbingan serta penerima bantuan yang rajin hadir dalam pendampingan. Alat bantu pendampingan berupa buku yang berisi materi yang sangat membantu dalam penyampaian Family Development Session (FDS). Tersedianya perlengkapan seperti alat tulis kantor yang lengkap, komputer dan printer di tiap-tiap kecamatan.

\section{SIMPULAN}

Peran pendamping PKH yang ada di Kecamatan Semarang Tengah telah melakukan perannya dengan baik. Peran tersebut dalam empat kategori, yaitu peran dan keterampilan fasilitatif, peran dan keterampilan sebagai pendidik, peran dan keterampilan representasi/perwakilan masyarakat, serta peran dan keterampilan teknis.

Faktor internal yang menjadi kendala dalam pendampingan adalah sulitnya peserta untuk mengumpulkan berkas data atau formulir pemutakhiran, pendamping memerlukan waktu 
untuk beradaptasi, serta sulitnya kehadiran peserta PKH untuk tepat waktu. Faktor eksternal yang menjadi kendala adalah informasi yang sifatnya mendadak, jarak tempuh pendamping ke tempat pendampingan cukup jauh, dan akses jalan yang sulit terjangkau. Faktor pendukung mencakup dukungan dari masyarakat penerima bantuan dan ibu-ibu yang rajin hadir, dan alat bantu pendampingan berupa buku yang berisi materi yang sangat membantu dalam penyampaian Family Development Session (FDS).

Peran seorang pendamping sudah cukup baik. Setidaknya jumlah pendamping ditambah. Penempatan pendamping sebaiknya dekat dengan domisili pendamping agar pendampingan lebih efektif tidak terkendala oleh jauhnya tempat pendampingan.

\section{DAFTAR PUSTAKA}

Damanik, J. (2008). Pekerjaan sosial. Jakarta:
Direktorat Pembinaan Sekolah Menengah Kejuruan, Direktorat Jenderal Manajemen Pendidikan Dasar dan Menengah Departemen Pendidikan Nasional.

Departemen Sosial. (2009). Bimbingan teknis PKH. Jakarta: Departemen Sosial Republik Indonesia.

Habibullah. (2011). Peran pendamping pada program keluarga harapan kabupaten karawang. Jurnal Informasi (Kajian Permasalahan Sosial Dan Usaha Kesejahteraan Sosial), 16(2), 101-116.

Hermawati, I. (2001). Metode dan teknik dalam praktek pekerjaan sosial. Yogyakarta: Adicita Karya Nusa.

Kementerian Sosial. (2016). Bimtek program keluarga harapan. Jakarta: Kementerian Sosial.

Moleong, L. J. (2010). Metodologi penelitian kualitatif. Bandung: PT Remaja Rosdakarya.

Rahayu, S. L. (2012). Bantuan sosial di Indonesia. Bandung: Fokusmedia. 